\title{
AECHMEA RUIZ \& PAV. (BROMELIACEAE) DO ESTADO DE PERNAMBUCO, BRASIL ${ }^{1}$
}

\author{
Gardene Maria de Sousa ${ }^{2}$ \\ Maria das Graças Lapa Wanderley ${ }^{3}$
}

Recebido em 22/01/1999. Aceito em 24/01/2000

\begin{abstract}
RESUMO - (Aechmea Ruiz \& Pav. (Bromeliaceae) do Estado de Pernambuco, Brasil). Foram registradas dez espécies do gênero Aechmea no Estado de Pernambuco: A. aquilega (Salisb.) Griseb., A. eurycorymbus Harms, A. fulgens Brongn., A. lingulata (L.) Baker, A. mertensii (G. Mey.) Schult. f. , A. mulfordii L. B. Sm., A. muricata (Arruda) L. B. Sm., A. stelligera L. B. Sm., A. tomentosa Mez e A. werdermannii Harms. Duas espécies são endêmicas ( $A$. muricata e $A$. werdermannii) e uma nova ocorrência $(A$. stelligera) foi referida para Pernambuco. São apresentados chave, descrições, ilustrações e comentários das espécies estudadas.
\end{abstract}

Palavras-chave - Aechmea, Bromeliaceae, taxonomia, Pernambuco, Brasil

ABSTRACT - (Aechmea Ruiz \& Pav. (Bromeliaceae) from Pernambuco State, Brazil). A taxonomic study of the genus Aechmea of Pernambuco, Brazil was done. Ten species were found: A. aquilega (Salisb.) Griseb., A. eurycorymbus Harms, A. fulgens Brongn., A. lingulata (L.) Baker, A. mertensii (G. Mey.) Schult. f., A. mulfordii L. B. Sm., A. muricata (Arruda) L. B. Sm., A. stelligera L. B. Sm., A. tomentosa Mez and $A$. werdermannii Harms. Aechmea muricata and A. werdermannii are endemic, and A. stelligera is a new records for Pernambuco State. Key, descriptions, comments and illustrations of the species are included.

Key words - Aechmea, Bromeliaceae, taxonomy, Pernambuco State, Brazil

\section{Introdução}

A família Bromeliaceae está representada no Estado de Pernambuco por 42 espécies e 16 gêneros (Andrade-Lima 1966a). Este autor realizou posteriormente inúmeras coletas em Pernambuco, estando a principal coleção depo- sitada no herbário IPA.

Com o objetivo de atualizar a Flora de Bromeliaceae de Pernambuco foi iniciado o estudo da família pelo gênero Aechmea, realizando levantamento preliminar nos principais herbários da região e coletas pelo período de dois anos nas diferentes localidades do Estado.

\footnotetext{
Parte da Dissertação de Mestrado da primeira Autora

2 Universidade Federal do Piauí, CCN, Departamento de Biologia, Campus Ministro Petrônio Portela, CEP 64049-550, Teresina, PI, Brasil, e-mail: gardene@ufpi.br

3 Instituto de Botânica, C. Postal 4005, CEP 01061-970, São Paulo, SP, Brasil, Bolsa Produtividade em Pesquisa do CNPq, email: gwanderley@smtp-gw.ibot.sp.gov.br
} 
Bromeliaceae é família de destaque para a flora de Pernambuco. Merecem ser mencionadas algumas espécies de valor econômico como o "abacaxi" (Ananas comosus (L.) Murril), o “caroá” (Neoglaziovia variegata (Arruda) Mez), produtora de fibras, e várias espécies ornamentais, como Billbergia morelli Brongn., Canistrum aurantiacum E. Morr., Cryptanthus zonatus (Vis.) Beer e Aechmea fulgens (Brongn.) Beer, entre outras (Andrade-Lima 1966a).

O Estado de Pernambuco está situado na região nordeste do Brasil ( $7^{\circ} 15^{\prime} 4^{\prime \prime}$ ' e $9^{\circ} 28^{\prime} 18^{\prime \prime} \mathrm{S}$ e $34^{\circ} 48^{\prime} 35^{\prime \prime}$ e $\left.41^{\circ} 19^{\prime} 54^{\prime \prime} \mathrm{W}\right)$. Abrange cerca de $98.281 \mathrm{~km}^{2}$, apresentando maior extensão de Leste para Oeste. Ocorrem no Estado florestas perenifólias e subcaducifólias, ocupando tanto as áreas da zona da mata costeira, como as de mata serrana. Esta última é regionalmente denominada "brejo de altitude," formando áreas úmidas dentro do domínio das caatingas, em altitudes superiores a 500 m.s.m. (Andrade-Lima 1960; 1966b; Vasconcelos Sobrinho 1971). Os representantes de Bromeliaceae são encontrados nos diferentes ambientes do Estado.

Aechmea Ruiz \& Pav., o maior e um dos mais complexos gênero de Bromeliaceae, pertence à subfamília Bromelioideae e reúne cerca de 172 espécies, agrupadas em oito subgêneros (Smith \& Downs 1979). Entretanto, este número está atualmente bastante ampliado, considerando as numerosas espécies novas descritas desde a publicação desse tratamento.

O gênero Aechmea é restrito ao Novo Mundo, com concentração de espécies no Brasil. Para o Estado de Pernambuco, Andrade-Lima (1966b) citou as seguintes espécies: A. aquilega (Salisb.) Griseb., A. eurycorymbus Harms, $A$. fulgens Brongn., A. lingulata (L.) Baker, A. mertensii (G. Mey.) Schult.f., A. muricata (Arruda) L. B. Sm., A. tomentosa $\mathrm{Mez}$ e $A$. werdermannii Harms.

Em levantamentos atuais nos herbários de Pernambuco, observou-se a ocorrência de outras espécies de Aechmea, além das já referidas por Andrade-Lima (1966a). Percebeu-se escas- sez de material de várias espécies, algumas delas conhecidas apenas pelo material-tipo. Procurou-se, dessa forma, realizar coletas nas diferentes regiões do Estado, inclusive no local dos materiais-tipos, para o melhor conhecimento da variabilidade das espécies e para a resolução de problemas taxonômicos do gênero.

\section{Material e métodos}

Para o presente trabalho foram revisados materiais dos seguintes herbários (abreviaturas segundo Holmgren et al. 1990; Barbosa \& Barbosa 1996): ALCB, B, CEPEC, EAC, EAN, HB, IAN, IPA, JPB, MG, MUFAL, NATAL, PEUFR, R, RB, SP, SPF, UB, UEC, HUEFS e UFP.

As descrições das espécies foram complementadas com as observações de campo, feitas em excursões botânicas realizadas em diferentes localidades do Estado de Pernambuco, no período de fevereiro/1995 a março/1996, além das informações das etiquetas dos materiais dos herbários. Os dados de distribuição geográfica foram baseados tanto nas informações de herbário como da literatura especializada (Fig. 1).

O material coletado encontra-se incorporado ao acervo do herbário UFP.

A terminologia morfológica usada segue Radford et al. (1974), Stearn (1992) e Font Quer (1993). Para as abreviaturas de obras usou-se Stafleu \& Cowan (1976-1988).

Os sinônimos citados foram baseados nos trabalhos de Baker (1879), Smith \& Downs (1979) e Read \& Luther (1991) e no exame de alguns materiais-tipos e descrições originais.

\section{Resultados e discussão}

\section{Aechmea Ruiz \& Pav.}

Erva terrestre, epífita ou rupícola; rizoma muitas vezes conspícuo. Folhas rosuladas, formando roseta aberta até tubular; bainha em geral alargada, lâminas com margens serradas ou serrilhadas. Escapo bem desenvolvido. Inflorescência simples a composta, flores em 

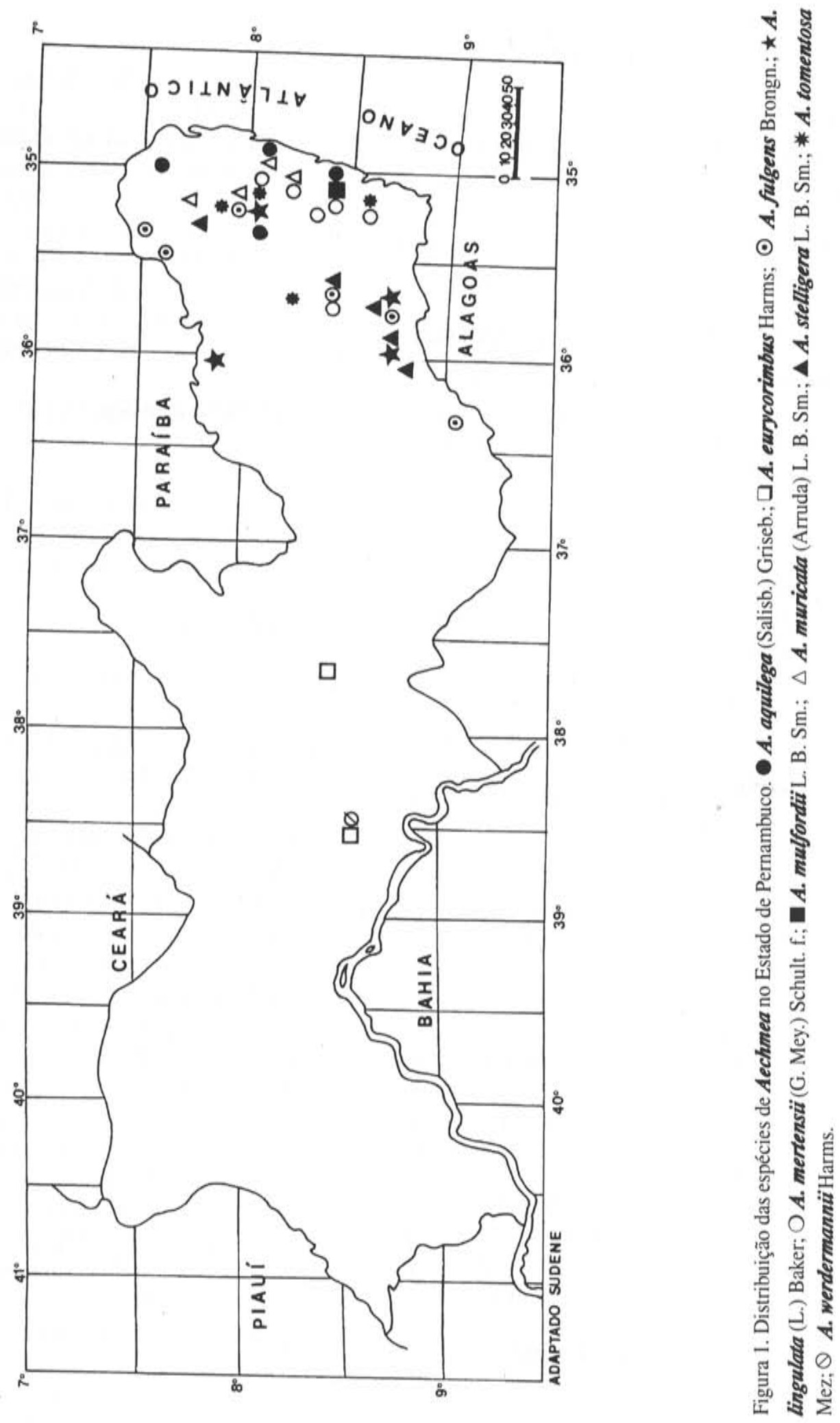
geral vistosas; brácteas florais vistosas a inconspícuas, algumas vezes ausentes; sépalas livres a conatas, em geral assimétricas e mucronadas; pétalas vermelhas, róseas, lilases, roxas, amarelas, esverdeadas ou brancas, com 2 apêndices petalinos internos; estames 6 , inclusos na corola, livres ou os do segundo ciclo adnatos às pétalas; ovário ínfero. Fruto baga. Sementes sem apêndices conspícuos.

\section{Chave para as espécies de Aechmea}

1. Inflorescência simples, estrobiliforme

7. A. muricata (subg. Chevaliera)

1. Inflorescência composta, cilíndrica a triangular

2. Inflorescência com ramificações apenas na base; bráctea floral ausente; pétalas lilases com margens mais claras

3. A. fulgens (subg. Lamprococcus)

2. Inflorescência composta com ramificações da base até o ápice; bráctea floral presente; pétalas brancas ou amarelas

3 . Flores $0,8-1,2 \mathrm{~cm}$ compr.

4. Pétalas alvas; inflorescência laxa; bráctea floral não envolvendo completamente o ovário

4. A. lingulata (subg. Aechmea)

4. Pétalas amarelas; inflorescência congesta; bráctea floral envolvendo completamente o ovário .

........ 5. A. mertensï (subg. Aechmea)

3. Flores $2,0-5,0 \mathrm{~cm}$ compr.

5. Inflorescência densamente escamosotomentosa; brácteas primárias cimbiformes

9. A. tomentosa (subg. Aechmea)

5. Inflorescência glabra ou levemente tomentosa; brácteas primárias lanceoladas, elíptico-lanceoladas ou oval-lanceoladas

6. Ramificações das inflorescências com flores laxas, não formando fascículos na extremidade dos ramos

7. Bráctea floral ultrapassando o ovário

2. A. exrycorymbus (subg. Aechmea)

7. Bráctea floral não ultrapassando o ovário.
8. Bráctea floral 2,3-3,0mm compr., face dorsal branco-tomentosa, ovário clavado

8. A. stelligera (subg. Aechmea)

8. Bráctea floral ca. $5 \mathrm{~mm}$ compr., glabra; ováriocilíndrico .....10. A. werdermannü (subg. Aechmea)

6. Ramificações das inflorescências com flores congestas, formando fascículos na extremidade dos ramos

9. Ramos de segunda ordem ca. $1 \mathrm{~cm}$ compr. 1. A. aquilega (subg. Aechmea)

9. Ramos de segunda ordem ca. $13 \mathrm{~cm}$ compr. 6. A. mulfordï (subg. Aechmea)

\section{Aechmea aquilega (Salisb.) Griseb., Fl. Brit.} W. I.: 592. 1864.

Fig. 2 A-F.

Bromelia aquilega Salisb., Parad. Lond. 1(2): 40. 1806. Tipo. Jamaica: D. Hurlocks.n. (Lectotipificada por Smith \& Downs In: Flora Neotropica. Bromelioideae-Bromeliaceae. Monografia 14(3): 1823. 1979.

Planta ca. $90 \mathrm{~cm}$ alt. Folhas verdes, revestidas em ambas as faces por escamas adpressas, lanceoladas, 0,65-1,20m compr., 2,4$6,0 \mathrm{~cm}$ larg., ápice pungente, múcron $3,0 \mathrm{~mm}$ compr., margens serradas, espinhos $3 \mathrm{~mm}$ compr.; bainha alargada, castanho-escura, 20,0$21,0 \mathrm{~cm}$ compr., 8,0-9,0 cm larg. Escapo ereto, vermelho a verde-alaranjado, lanuginoso, 30,0$70,0 \mathrm{~cm}$ compr. Brácteas do escapo coriáceas, conduplicadas, pardo-claras, as basais densamente imbricadas e foliáceas, as demais menores e laxas, lanceoladas, ultrapassando os entrenós, 6,0-10,5cm compr., 2,5-3,5cm larg., ápice acuminado, margens inteiras. Inflorescência composta, panícula congesta, fasciculada na extremidade dos ramos, levemente tomentosa, cilíndrica a triangular, $15-19 \mathrm{~cm}$ compr., 9-12cm larg., ramos de segunda ordem curtos, ca. $1,0 \mathrm{~cm}$ compr. Brácteas primárias papiráceas, vermelhas, patentes, lanceoladas a elíptico-lanceoladas, 3,0-9,5cm compr., 1,0$1,5 \mathrm{~cm}$ larg., em geral mais longas que os fascículos de flores, margens inteiras. Brácteas secundárias papiráceas, alaranjadas, base 


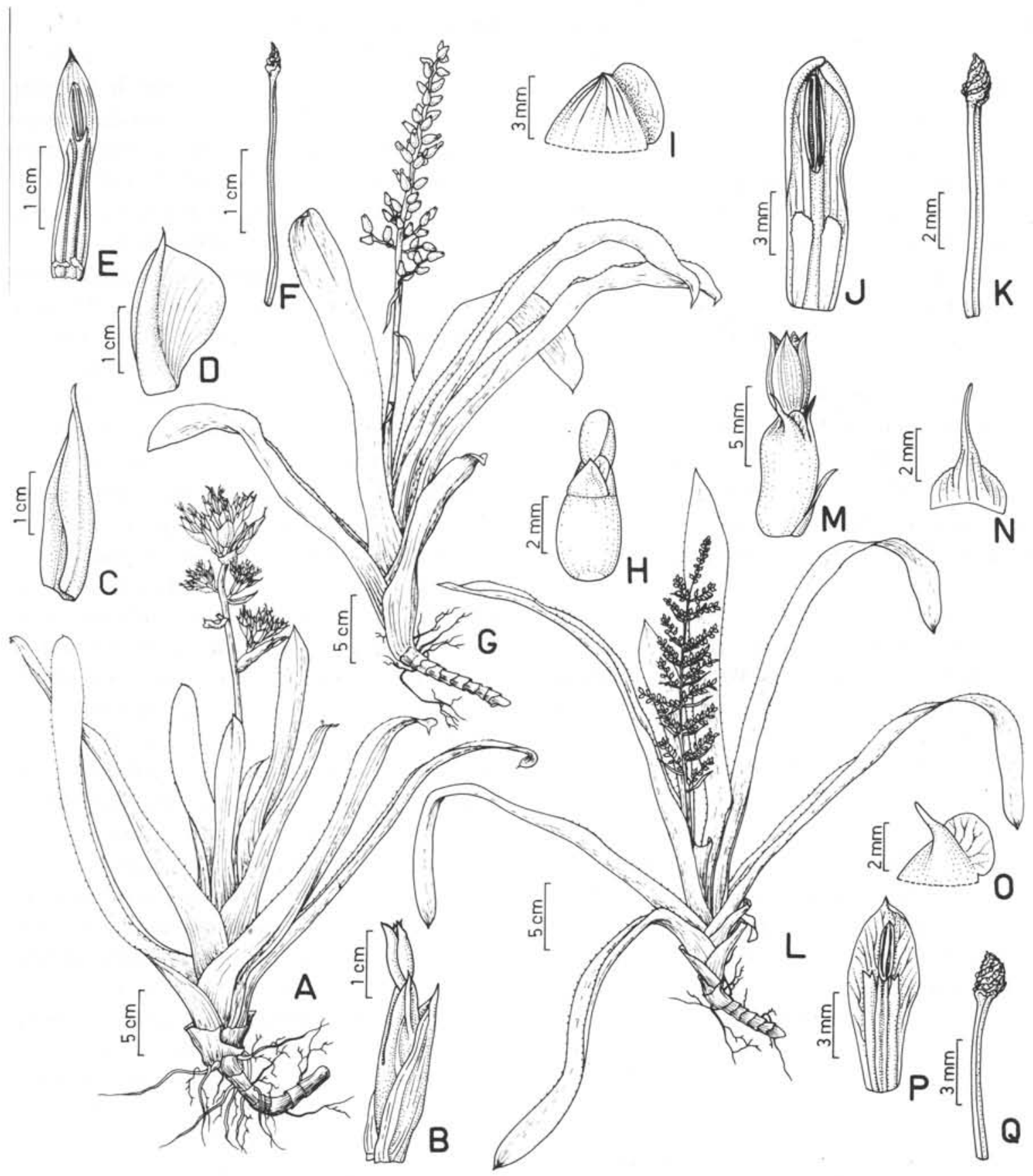

Figura 2. A-F. Aechmea aquilega. A. hábito; B. flor; C. bráctea floral; D. sépala; E. pétala, estame e apêndices petalinos; F. estilete e estigma (Sousa et al. 176). G-K. Aechmea fulgens. G. hábito; H. flor; I. sépala ; J. pétala, estame e apêndices petalinos; K. estilete e estigma (Sousa et al. 86). L-Q. Aechmea lingulata. L. hábito; M. flor; N. bráctea floral; O. sépala; P. pétala, estame e apêndices petalinos; Q. estilete e estigma (Sousa \& Wanderley 165). 
esverdeada, carenadas, ovais, 2,0-2,5cm compr. Bráctea floral semelhante às brácteas secundárias, 3,0-3,1 cm compr., ápice pungente e pubescente, margens inteiras, ultrapassando completamente o ovário. Flores sésseis, 3,5$4,2 \mathrm{~cm}$ compr. Sépalas livres, amareloesverdeadas, bilateralmente assimétricas, 1,6$1,7 \mathrm{~cm}$ compr., 0,7-0,8cm larg., levemente carenadas, ápice acuminado. Pétalas livres, amarelas, 2,4-2,5cm de compr., ca. $3 \mathrm{~mm}$ larg., base ligulada, lobo da pétala oval, ápice agudo; apêndices petalinos basais, ligulados, conatos à base das pétalas, porção apical livre, ápice levemente truncado, margens erosas, 3,0 mm compr. Estames com filete de ca. $1,7 \mathrm{~cm}$ compr., antera ca. $6,0 \mathrm{~mm}$ compr. Estigma cilíndrico, $2,6 \mathrm{~cm}$ compr., lobo espiralado, ultrapassando levemente as anteras. Tubo epígino ca. $3 \mathrm{~mm}$ compr. Ovário glabro, trígono, $8,0 \mathrm{~mm}$ compr., $5,0 \mathrm{~mm}$ larg., liso. Placentação axial, ocupando metade da cavidade do ovário. Óvulos numerosos, caudados. Frutos e sementes não vistos.

Material examinado: BRASIL. Pernambuco: Cabo, Mata de Gurjaú, 16/III/1994, Luceño et al. s.n. (UFP); Goiana, Estação experimental do IPA, 27/II/1996, Sousa et al. 176 (UFP); 27/II/1996, Sousa et al. 177 (UFP); 27/II/1996, Sousa et al. 178 (UFP); Recife, Aeroporto, 16/XII/1995, fl., Sousa et al. 174 (cultivada) (UFP); Campus UFPE, 15/I/1996, fl., Sousa et al. 175 (cultivada) (UFP); Jardim Botânico do Curado, 25/II/1992, Pereira et al. 766 (IPA); São Lourenço da Mata, Tapera, XII/1929, fl., Pickel s.n. (IPA 3492).

Material adicional selecionado: BRASIL. Ceará: Pacoti, XII/1986, fl., Verde s.n. (EAC 15694); Serra de Maranguape, 24/XI/1955, Andrade-Lima 55-2390 (IPA).Rio Grande do Norte: Natal, 31/X/1992, Félix 5458 (EAN). Paraíba: Areia, 11/XII/1958, Morais s.n. (EAN). Alagoas: Coruripe, 2/II/1982, fl., Kirkbride s.n. (UB 4633); Marechal Deodoro, entrocamento da AL 101 Sul, XII/1992, fl., Silva s.n. (MUFAL 00622); APA de Santa Rita,
27/I/1987, Esteves \& Lyra-Lemos 1796 (SP).

Bahia: Castro Alves, 26/I/1956, fl., AndradeLima 56-2498(IPA); Rio do Peixe, 10/XI/1973, fl, Costa s.n. (ALCB 00277). Rio de Janeiro: Itabaianinha, em direção ao Povoado Campo Grande, 19/IX/1974, Fonseca s.n. (RB); Jardim Botânico (cultivada), 23/9/1945, fl., Voll s.n. (RB 6253). Paraná: Curitiba, cultivada na Reserva Biológica de Sapitanduva (HB 75893).

Aechmea aquilega distribui-se nos Estados do Ceará, Rio Grande do Norte, Paraíba, Pernambuco, Alagoas, Bahia e Rio de Janeiro, ocorrendo como epífita, terrestre ou rupícola nas matas, restingas e caatinga. Floresce nos meses de novembro a fevereiro e frutifica em março e abril. Foi inicialmente descrita como Bromelia aquilega por Salisbury \& Hooker (1806), com base em material cultivado, procedente da Jamaica. A tipificação é baseada na prancha original, pela não preservação do material em herbário. Esta espécie foi transferida para o gênero Aechmea por Grisebach (1864). Smith \& Downs (1979) consideraram duas variedades de A. aquilega: $A$. aquilega var. aquilega e $A$. aquilega var. chrysocoma (Baker) L. B. Sm., distintas essencialmente pela coloração das brácteas florais verde-escuros e amarelo-brilhantes, respectivamente. $\mathrm{O}$ exame desta espécie no campo e das plantas cultivadas mostrou a grande variação, não só em relação à coloração da bráctea floral, como também em relação à forma e coloração das folhas e da inflorescência. Em plantas cultivadas, ou mesmo nas de ambientes abertos, as folhas são caracteristicamente amareladas, diferindo das folhas verde-escuras dos espécimes que vivem à sombra na mata. Considerando que estas diferenças de coloração das brácteas e folhas são características pouco consistentes, que se modificam em função da maior ou menor incidência da luz solar, a variedade crysocoma foi aceita na sinonímia de $A$. aquilega, como proposto por Read \& Luther (1991).

A inflorescência pode apresentar grande variação quanto à forma, desde capitada à cilín- 
drica, com flores em geral densamente dispostas. É possível que esta variação tenha levado diferentes autores a criar vários nomes para $A$. aquilega, como $A$. exsudans (Lodd.) Baker, sinonimizada em $A$. aquilega por Smith \& Downs (1979), A. capitata (Schult. f.) Baker e A. aquilega var. chrysocoma, sinonimizadas por Read \& Luther (1991) em A. aquilega. Segundo esses últimos autores, A. aquilega var. chrysocoma, estabelecida por Smith \& Downs (1979), em nada difere de $A$. capitata, espécie conhecida apenas por uma única coleta. Os autores observaram que os caracteres utilizados para separar estes dois táxons são influenciados pelas diferentes condições ambientais, como a maior ou menor exposição luminosa. Destacam ainda que inflorescência capituliforme, composta por três espigas estrobiliformes densas, oblongas ou subglobosas são comuns a esses dois táxons.

Aechmea aquilega apresenta semelhança com A. mulfordii L. B. Sm., ambas com inflorescência composta por fascículos capitados e forma e coloração das brácteas secundárias e florais semelhantes.

O material Ana Lima 50-68 (IPA), identificado como $A$. mulfordii, possui inflorescência que representa o extremo da variação que ocorre para $A$. aquilega, com ramos mais alongados, principal característica que separa esta espécie de $A$. mulfordii, com grande possibilidade, portanto de que sejam sinônimos. Como não foi possível examinar o material-tipo de $A$. mulfordii, não foi efetuada a sinonimização.

2. Aechmea eurycorymbus Harms, Notizbl. Bot. Gart. Berlin-Dahlen 12: 528. 1935. Tipo. Brasil. Pernambuco: Floresta, Serra Negra, março 1932, Werdermann 2931 (Holótipo B; Foto B 1192/32)

Planta ca. de $2 \mathrm{~m}$ alt. Folhas lanceoladas, ápice pungente, margens serradas. Brácteas do escapo papiráceas, rosadas, oval-lanceoladas, ápice pungente, $14,0 \mathrm{~cm}$ compr., 2,6cm larg. Inflorescência composta, panícula amplamente ramificada, (3-4 pinada), laxa, glabra, ramificações anguladas. Brácteas primárias papiráceas, oval-lanceoladas, $3,0-10,5 \mathrm{~cm}$ compr., $0,5-2,0 \mathrm{~cm}$ larg. Brácteas secundárias lanceoladas, membranáceas, 7,0mm compr., aristadas. Bráctea floral diminuta, oval, 8,0mm compr., ápice mucronado, margens inteiras, ultrapassando o ovário. Flores sésseis, ca. 2,0cm compr. Sépalas livres, rígidas, fortemente assimétricas, torcidas, oval, ca. $1,5 \mathrm{~cm}$ compr., ápice mucronado, oblíquo. Pétalas livres, amarelas, base ligulada, lobo da pétala lanceolado, ca. 2,0cm compr., 2,0mm larg., agudo; apêndices petalinos basais, ca. 2,0mm compr., conatos à base das pétalas, porção apical livre, ápice levemente truncado, margens erosas. Estames inclusos, do mesmo compr. das pétalas; anteras $6 \mathrm{~mm}$ compr. Estigma contorcido-espiralado. Tubo epígino ca. 2,0mm compr. Ovário liso, glabro, ca. $6,0 \mathrm{~mm}$ compr. Placentação axial ocupando ca. da metade da cavidade do ovário. Óvulos numerosos, caudados. Fruto e sementes não vistos.

Material examinado: BRASIL. Pernambuco: Ibimirim, 25/XI/1961, Mee s.n. (SP 69033).

Aechmea eurycorymbus foi descrita por Harms (1935) que a considerou relacionada a A. pyramidalis Benth. pela inflorescência paniculada com muitas flores, apresentando esta última menor pilosidade e flores muito pequenas, e não ocorrendo no Brasil. Aechmea. eurycorimbus parece mais relacionada a $A$. werdermanii Harms, descrita na mesma obra da primeira. Estas duas espécies apresentam o mesmo padrão de inflorescência, amplamente ramificada, incluindo ainda no mesmo grupo $A$. stelligera L. B. Sm. e A. tomentosa Mez. Observa-se nestas espécies tendência ao encurtamento das ramificações terciárias da inflorescência, sendo mais longas em $A$. werdermannii e $A$. eurycorymbus, tornando-se gradativamente mais curtas em A. stelligera e $A$. tomentosa.

Os limites entre $A$. eurycorymbus e $A$. werdermannii não são muitos claros, dificulta- 
dos pela falta de novas coletas de $A$. eurycorymbus e pela impossibilidade do exame do material-tipo da mesma. O único exemplar examinado possui apenas flores jovens, o que não permitiu descrição detalhada da espécie. É possivel que as diferenças utilizadas para separar estas duas espécies sejam provavelmente em função das diferentes fases de desenvolvimento das partes reprodutivas representadas nas coleções de herbário, estando o material-tipo de $A$. werdermannii em fruto. Para melhor compreensão será necessário o exame de novas coleções, incluindo o material-tipo de $A$. eurycorymbus.

3. Aechmea fulgens Brongn., Ann. Sci. Nat. Bot. 2.(15): 371. 1841.

Fig. 2 G-K.

Lamprococcus fulgens (Brongn.) Beer, Fam. Bromel.: 103. 1857. Tipo. Guiana: próximo a Caiena, cultivada no Museu de Paris. Quesnel s.n. (Holótipo P).

Planta ca. $30,0-80,0 \mathrm{~cm}$ alt. Folhas verdes, $16,0-63,0 \mathrm{~cm}$ compr., 2,6-6,3cm larg., revestidas por escamas castanhas, esparsas na lâmina, densamente dispostas na bainha, ápice acuminado, margens inconspicuamente serradas, espinhos esparsos, até $0,5 \mathrm{~mm}$ compr.; bainha oval, mais clara que a lâmina, 12,0-16,0cm compr., 4,0$9,5 \mathrm{~cm}$ larg. Escapo ereto, glabro, vináceo, 11,0$37,0 \mathrm{~cm}$ compr. Brácteas do escapo membranáceas, vináceas, lanceoladas, 5,0$12,0 \mathrm{~cm}$ compr., ca. 9,0 mm larg., ápice agudo, margens inteiras, ultrapassando os entrenós, reflexas, a superior ultrapassando a primeira ramificação da inflorescência, as basais foliáceas, margens lisas e densamente dispostas. Inflorescência simples, espiciforme, raros ramos basais, com 4-6 flores laxamente dispostas, 10,0$28,0 \mathrm{~cm}$ compr., $2,5-8,0 \mathrm{~cm}$ larg. na base, raque vermelho. Bráctea floral ausente. Flores sésseis, 1,8-2,0cm compr. Sépalas livres, fortemente assimétricas, vermelhas com ápice lilás, obtusas, base crassa, 3,5-4,0mm compr. Pétalas li- vres, lilases, 1,0-1,3cm compr., ca. 3,0mm larg., com margens mais claras, liguladas, lobo oval, cuculado, emarginado; apêndices petalinos basais crassos, liguliformes, ca. de $5,0 \mathrm{~mm}$ compr., conatos até o terço inferior das pétalas, margens serrado-fimbriadas. Estames com filete $8,0 \mathrm{~mm}$ compr., antera $5,0 \mathrm{~mm}$ compr. Estigma cilíndrico, ca. $9,0 \mathrm{~mm}$ compr., lobo espiralado, margens onduladas, atingindo a parte mediana das anteras. Tubo epígino ca. $1,0 \mathrm{~mm}$ compr. Ovário cilíndrico, vermelho, glabro, liso, 7,0mm compr., 5,0mm larg. Placentação apical. Óvulos numerosos, caudados. Fruto baga, vináceo, ca.1,2cm compr., 5,0mm larg. Sementes obovóides, ca. 1,5mm compr., 0,5mm larg.

Material examinado: BRASIL. Pernambuco: Bonito, Reserva Ecológica de Bonito, 15/III/1995, fl., Sousa et al. 86 (UFP); Maraial, Lagoa dos Gatos, Serra do Urubu, 20/V/1994, fr., Miranda et al. 1595 (PEUFR); Fazenda Céu Azul, 13/X/1957, Andrade-Lima 57-2738(IPA). Palmeirinha, X/1985, fl., Félix 1785 (EAN); Quipapá, Engenho Brejinho, 22/III/1967, fl, Andrade-Lima 67-4977(IPA); São Lourenço da Mata, Estação Ecológica de Tapacurá, Mata do Camocim, 2/XII/1977, Pontual 77-1312 (PEUFR); 10/IV/1990, Moura s.n. (PEUFR 10123); 6/VI/1995, fr., Sousa et al. 127 (UFP); Engenho São Bento, Tapera, 26/XII/1964, Lima 63-4187(PEUFR); 1927, Pickel s.n. (IPA 6332); V/1927, Pickels.n. (IPA 6334); 17/I/1930, Pickel s.n. (IPA 3494); São Vicente Ferrer, Mata do Estado, 28/IV/1995, fl., Sousa et al. 97 (UFP); 18/IV/1995, fl., Villarouco et al. 42 (PEUFR); Timbaúba, Eng. Água Azul, 26/II/1969, Andrade-Lima 69-5541(IPA).

Material adicional selecionado: BRASIL. Bahia: Aurelino Leal, $11 \mathrm{~km}$ W da BR 101, 3/V/1992, fr., Thomas et al. s.n. (CEPEC 56504; ALCB). Rio de Janeiro: Barra da Guaratiba, Sítio Roberto Burle Marx (cultivada), 8/IV/1988, Chamas s.n. (RB).

Aechmea fulgens distribui-se pelos Estados de Pernambuco, Bahia e Rio de Janeiro, 
ocorrendo como epífita e terrestre nas matas e em vegetação de restinga. Floresce nos meses de janeiro a abril e frutifica de maio a julho. Esta espécie possui afinidades morfológicas com A. miniata (Beer) Baker, referida apenas para a Bahia, em relação ao hábito, forma da inflorescência e coloração das brácteas e das flores. Diferencia-se essecialmente pela inflorescência com ramificações desde a base até o ápice em $A$. miniata, enquanto em $A$. fulgens os ramos são apenas basais. Em função destas semelhanças, alguns exemplares de herbário de $A$. fulgens são identificados como A. miniata. A. warasii E. Pereira também apresenta afinidades com $A$. fulgens, da qual se separa por apresentar ovário verrucoso.

Smith \& Downs (1979) consideraram duas variedades para $A$. fulgens. A variedade fulgens tem folhas completamente verdes, e a variedade discolor (E. Morr.) Brongn. ex Baker, folhas verde-púrpuras na face abaxial. Estas variações não foram observadas nitidamente nos materiais vivos e são pouco claras no material de herbário. Apenas o material Sousa et al. 86 apresentou pequena diferenciação entre as duas faces da folha, o que poderia constituir um exemplar da variedade discolor. Pela falta de nítida diferenciação entre as coleções examinadas optou-se por não utilizar a divisão infra-específica para a espécie.

\section{Aechmea lingulata (L.) Baker, J. Bot. London} 17: 164. 1879.

Fig. 2 L-Q.

Bromelia lingulata L. Sp. pl.: 285. 1753. Tipo: América Meridional, Plumier s.n. (Holótipo P).

Planta ca. $1,30 \mathrm{~m}$ alt. Folhas verdes a verdevináceas, liguladas, 0,23-1,25m compr., 3,2$7,0 \mathrm{~cm}$ larg., ápice abruptamente triangular, distinto, negro, pungente, espinho apical ca. $1,0 \mathrm{~cm}$, margens densamente serradas, espinhos negros, até $3 \mathrm{~mm}$ compr.; bainha castanho-vinácea, 4,029,0cm compr., 4,0-11,0cm larg. Escapo ereto, esverdeado, 31,0-57,0cm compr., lanuginoso, tricomas alvos. Brácteas do escapo papiráceas, cremes a vináceas, lanuginosas, espiraladas, lanceoladas, longo-acuminadas, $7,5-9,0 \mathrm{~cm}$ compr., 1,0-1,8cm larg., margens inteiras, geralmente ultrapassando os entrenós, as basais imbricadas, foliáceas com margens serradas. Inflorescência composta, panícula de espiga, laxa, sub-piramidal, 24,0-48,0cm compr., 10,0$40,0 \mathrm{~cm}$ larg. Brácteas primárias membranáceas, vináceas, margens lisas, patentes, lanceoladas, $3,0-7,0 \mathrm{~cm}$ compr., gradativamente menores para o ápice. Bráctea floral coriácea, inconspícua, deixando visível quase todo o ovário, verde, oval, assimétrica, longo-aristada, 4,5-5,0 mm compr., lanuginosa, margens levemente serrilhadas. Flores sésseis, 1,0-1,2cm compr. Sépalas livres, esverdeadas, fortemente assimétricas, ca. $3,0 \mathrm{~mm}$ compr., ápice aristado. Pétalas livres, brancas, 7,5-8,0mm de compr., ca. 2,5mm larg., ligulada na base, com lobos elípticos ápice obtuso-atenuado; apêndices petalinos calosos da base da pétala até a base da antera, ápice inconspícuo, bífido, calosidades e apêndices com $5,0 \mathrm{~mm}$ compr. Estames com filete ca. 6,0mm compr., antera 2,5mm de compr. Estigma cilíndrico, ca. $8,0 \mathrm{~mm}$ compr., lobos espiralados, margens onduladas e glandulosas, da mesma altura das anteras. Tubo epígino ca. $0,5 \mathrm{~mm}$ compr. Ovário cilíndrico a tubular, ca. $4,0 \times 3,0 \mathrm{~mm}$, liso. Placentação apical. Óvulos pêndulos, numerosos, obtusos. Fruto baga, vináceo, ca. $8,0 \mathrm{~mm}$ compr., 5,0mm larg. Sementes obovóides, ca. 2,5mm compr., $0,5 \mathrm{~mm}$ larg.

Material examinado: BRASIL. Pernambuco: Bezerros, Serra Negra de Bezerros, 4/III/1996, fr., Sousa et al. 182 (UFP); Estrada para Caruaru, 7/X/1938, Xavier s.n. (JPB 01); Maraial, Lagoa dos Gatos, 28/XI/1995, fr., Sousa et al. 172 (UFP); Taquaritinga do Norte, Sítio Cafundó, 26/VIII/1995, Sousa et al. 148 (UFP). São Benedito do Sul, Mijada da Veia, 4/XI/1995, fr., Sousa et al. 166 (UFP); 4/XI/1995, Sousa et al. 167 (UFP); 4/XI/1995, Sousa et al. 168(UFP); São Lourenço da Mata, Mata do Toró, 28/IX/1995, fl., Sousa \& 


\section{Wanderley 165 (UFP).}

Material adicional selecionado: BRASIL. Ceará: Serra de Maranguape, 22/XI/1955, Andrade-Lima 55-2333 (IPA); 24/XI/1955, Andrade-Lima 55-2382 (IPA). Rio Grande do Norte: Natal $05^{\circ} 48^{\prime} 00^{\prime} \mathrm{S}, 35^{\circ} 13^{\prime} 00^{\prime \prime} \mathrm{W}$, 16/XI/1980, fl., Projeto Parque das Dunas (Natal). Paraiba: Mamanguape, Reserva florestal do INCRA, 26/X/1982, fl., Miranda et al. 177 (JPB). Alagoas: União dos Palmares, Faz. Santo Antônio, 5/I/1964, fr., Pontual 44-64 (PEUFR); 6/II/1966, fl., Pontual 66-262 (PEUFR); Colônia Leopoldina, Eng. São Sebastião, 1/XI/1957, fr., Andrade-Lima 57-2769 (IPA); 1/XI/1957, fl., Andrade-Lima 57-2769 (IPA). Bahia: Água Preta, 2/VI/1939, fr., Foster $58(\mathrm{R}) ; 2 / \mathrm{VI} / 1939$, fr., Foster 61 (R); Belmonte, $25 \mathrm{~km}$ da cidade, 6/I/1981, fl., Carvalho \& Gatti s.n. (CEPEC 22817); Cairu, 14/VIII/1993, Guedes et al. s.n. (ALCB 026426); Feira de Santana, Serra de São José, 20/IX/1980, Noblick s.n. (HUEFS; RB); Geolândia, Vale dos rios Paraguaçu e Jacuípe, IX/1980, fr., Scardino et al. 682 (CEPEC; ALCB); 25/IX/1980, Scardino et al. s.n. (UEC 28871). Espírito Santo: Colatina, 2/VIII/1940, Foster \& Foster s.n. (SP). Rio de Janeiro: Araruama, 17/IX/1980, Carlos \& Gurken 22 (HB); Cabo Frio, 14/X/1968, Sucre 3943 (RB); Casimiro de Abreu, Distrito Barra de São José, 1956, Segadas-Viana et al. s.n. ( $\mathrm{R}$ 186727); Cabo Frio, $\mathrm{X} / 1889$, Ule s.n. ( $\mathrm{R}$ 46489); Costa et al. 5 (RB); Santa Maria Madalena, 30/VI/1972, Farney 1459 (RB). São Paulo: São Paulo, Mata da Reserva da Cidade Universitária, 10/XI/1982, Matos s.n. (SPF).

Aechmea lingulata apresenta ampla distribuição geográfica, ocorrendo na Costa Rica, Bahamas, Ilhas Virgínia, Ilhas Barlavento, Ilhas Sotavento, Venezuela, Trinidade, Tobago, Suriname, Guiana Francesa e Brasil (Smith \& Downs 1979). No Brasil há registros para os Estados do Ceará, Rio Grande do Norte, Paraíba, Pernambuco, Alagoas, Bahia, São Paulo, Rio de Janeiro e Espírito Santo, onde ocorre como epífita ou terrestre em matas, vegetação de restinga, campo rupestre e caatinga. É abundante em Pernambuco, estando presente nas matas do norte e do sul do Estado, com registro de grandes populações nos municípios de Maraial e Taquaritinga do Norte. Floresce nos meses de agosto a outubro, com frutificação em outubronovembro. As flores apresentam aroma forte $\mathrm{e}$ adocicado, tendo sido observada a visita de abelhas.

Aechmea ligulata foi descrita por Baker (1879) como pertencente à secção Pironneava Gaudch. Em 1889 este autor elevou esta secção a gênero. Mez (1896; 1935) classificou-a como Wittmackia lingulata, sendo então transferida por Smith (1955) para o gênero Aechmea.

Smith (1955) dividiu esta espécie em duas variedades, A. lingulata var. froesii e Aechmea lingulata var. patentissima (Mart. ex Schult. f.) L. B. Sm. separadas basicamente pela direção dos ramos da inflorescência, forma da bráctea floral e tamanho das sépalas. Estas variedades não foram adotadas no presente trabalho pelo fato dos exemplares de Pernambuco não exibirem variações significativas quanto aos caracteres usados na separação das mesmas.

5. Aechmea mertensü (G. Mey.) Schult. f. in Roem. \& Schult., Syst. veg. 7(2): 1272. 1830. Fig. 3 A-F.

Bromelia mertensii G. Mey., Prim. fl. esseq.: 144. 1818. Tipo. Guiana: próximo a foz do Rio Essequibo, Rodschied s.n. (GOET).

Planta ca. de $15,0-42,0 \mathrm{~cm}$ alt., roseta com ca. 6 folhas. Folhas verdes, lanceoladas, revestidas de escamas, 14,0-41,0cm compr., 0,6$1,5 \mathrm{~cm}$ larg., ápice atenuado, ca. $0,5 \mathrm{~mm}$ compr., margens serradas, espinhos ca. de $1,5 \mathrm{~mm}$ compr.; bainha levemente castanha, alargada, 4,0-6,0cm compr., 1,3-1,7cm larg. Escapo delicado, glabro, ereto, vináceo, $5,0-19,0 \mathrm{~cm}$ compr. Brácteas do escapo membranáceas, vermelhas, alternas, elípticas, 2,5-2,8cm compr., 5,5-6,0mm larg., ápice pungente, margens serradas, geralmente mais curtas que os entrenós, as superiores mais longas. Inflorescência 


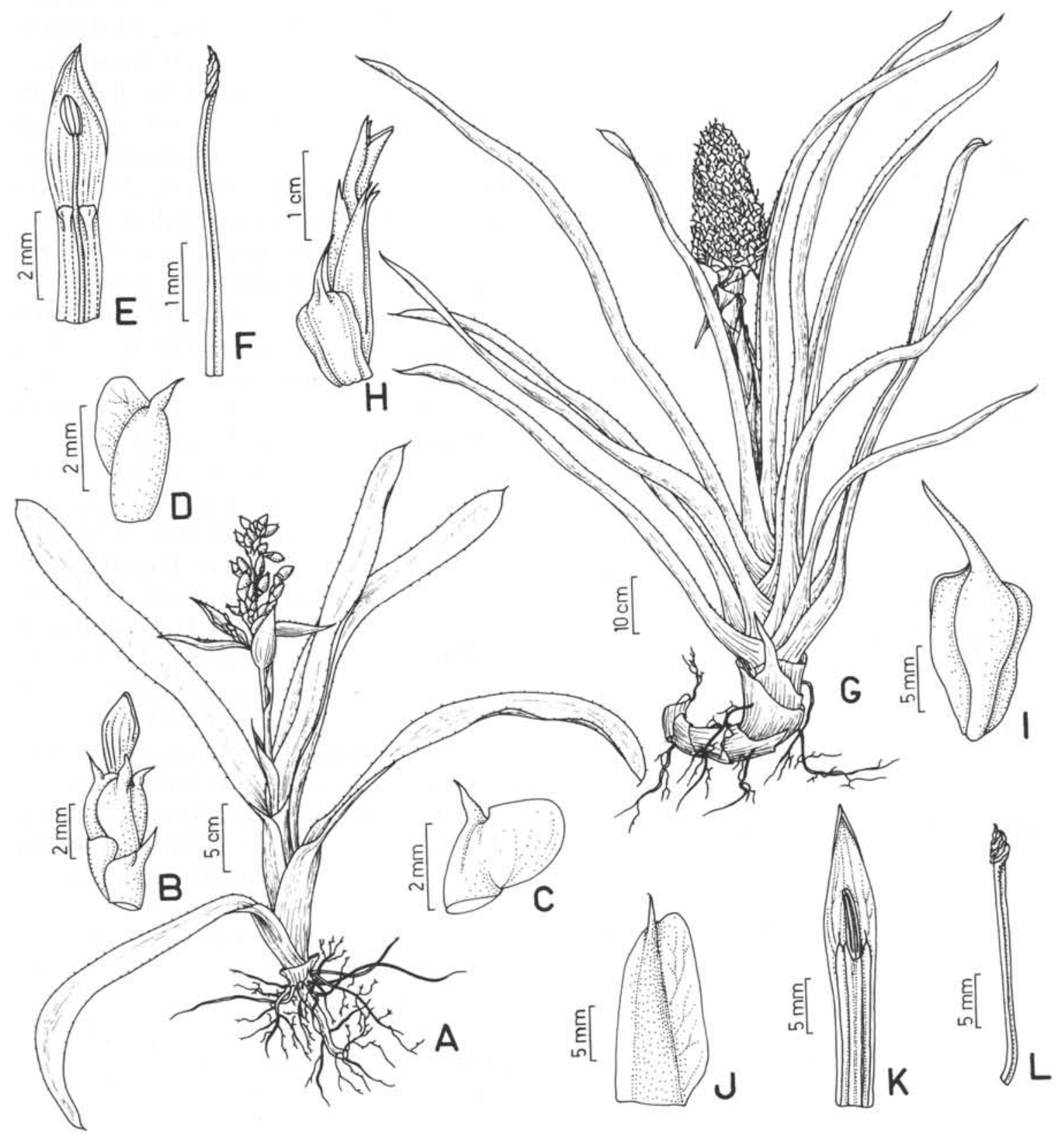

Figura 3. A-F Aechmea mertensii. A. hábito; B. flor; C. bráctea floral; D. sépala; E. pétala, estame e apêndices petalinos; F. estilete e estigma (Sousa et al. 126). G-L. Aechmea muricata. G. hábito; H. flor; I. bráctea floral; J. sépala; K. pétala, estame e apêndices petalinoss; L. estilete e estigma (Sousa et al. 169). 
composta, panícula de espigas, congesta, 2,5$8,0 \mathrm{~cm}$ compr., 2,0-2,5cm larg. Brácteas primárias membranáceas, vermelhas, vistosas, ovadas a elípticas, margens serradas, patentes, ápice agudo, 2,5-3,5cm compr., 5,0-8,0 mm larg. Bráctea floral papirácea, amarelo-esverdeada, ca. 3,5mm compr., conduplicada, envolvendo completamente o ovário, mucronada, margens expandidas, inteiras. Flores sésseis, $0,8-0,9 \mathrm{~cm}$ compr. Sépalas livres, amarelo-esverdeadas, fortemente assimétricas, um dos lobos distintamente maior, levemente crassas, ca. 2,5mm compr., ápice mucronado. Pétalas livres, amarelas, 5,5-6,5mm compr., ca. 1,0mm larg., base ligulada, lobo elíptico, ápice mucronado, múcron carnoso; apêndices petalinos inconspícuos, visível apenas na metade da pétala, conatos às pétalas, membranáceos, livres na porção mediana, franjados, ca. $2,5 \mathrm{~mm}$ compr. Estames com filete ca. 5,0mm compr., antera $1,0 \mathrm{~mm}$ compr. Estigma cilíndrico, ca. $5,0 \mathrm{~mm}$, lobos espiralados, margens onduladas, da mesma altura das anteras. Tubo epígino quase nulo. Ovário obovóide, ca. 2,5mm compr., 1,5mm larg., liso. Placentação apical. Óvulos poucos, caudados. Fruto baga, globoso, quando jovem verde e na maturidade azul-arroxeado, liso, $7,5 \mathrm{~mm}$ compr., 2,5mm larg. Sementes obovóides, caudadas, 2,5-3,5mm compr., 0,5-1,0 $\mathrm{mm}$ larg.

Material examinado: BRASIL. Pernambuco: Bonito, Reserva Municipal, 24/XI/1994, fl., Felix 7005 (PEUFR); Cabo, Pontezinha, I/1962, fl., Sarmento 454-A (PEUFR); Escada, Usina União Indústria, 7/III/1968, fl., Ferreira 45-68 (IPA; SP); Jaboatão dos Guararapes, Engenho Camacuru, 19/V/1932, fl., Pickel s.n. (IPA 3495); Ribeirão-Airipibú, 4/XII/1933, Pickel s.n. (IPA 6318); Rio Formoso, próximo à Reserva Ecológica de Saltinho, 26/V/1994, Sousa \& Wanderley 26 (UFP); São Lourenço da Mata, Mata do Toró, 26/XII/1963, fl., Andrade-Lima 63-4186 (IPA).

Material adicional selecionado: BRASIL.

Rondonia: Abuna, 14/IX/1963, Maguire et al. s.n. (RB); Seringal São Luiz, 31/III/1978, Santos et al. 297 (IAN); Porto Velho, 24/IX/1963, Pires 56780 (UB); BR 29, km 236 Porto Velho, 9/IX/1962, Duarte 7033 (RB). Amazonas: Manaus, Flores, km 6, 15/IX/1955, Rodrigues s.n. (UB 15793); São Raimundo,24/VIII/1928, Luetzelburg 22099(R); Reserva Florestal Ducke, 23/I/1963, Fromm et al. 1424 (R); Igarapé da cachoeira alta do Tarumã,3/I/1955 fl., Chagas s.n. (UB 15792); km 55 da Rodovia ManausItacoatiara, 25/V/1963, Oliveira 2803 (UB); Estrada Manaus-Boa Vista, 2/II/1984, Farney et al. 415(RB). Amapá: Rio Puchaca, 15/II/1961, Emmerich 815 \& Andrade (R); Seringal São Luis, 31/III/1978, Santos et al. 297(MG). Pará: Altamira, margens esquerda do Rio Xingú, 11/X/1986, Vasconcelos et al. 236 (MG); 18/X/1986, Vasconcelos et al. 338 (IAN). Maranhão: Bom Jardim, Posto Indígena Carú, 28/VIII/1983, Balick et al. s.n. (CEN); Monção, Margem do Rio Pindaré, 3/X/1987, Haas et al. 02 (RB); Turiaçu, Km 6 BR 106, 29/XI/1978, Rosa \& Vilar 2734 (MG). Paraíba: Mamanguape, Cabeça de Boi, Sema III, 24/V/1990, Felix \& Santana 3065 (JPB, EAN); Sema III, 19/VIII/1996 Félix \& Miranda s.n. (IAN); Rio Tinto, Estação Ecológica, 19/VIII/1988, (JPB 15658); Santa Rita: Km 52, 14/IV/1980, Agra s.n. (RB). Alagoas: Colônia Leopoldina, Eng. São Sebastião, 1/XI/1957, fl., Andrade-Lima 57 2767 (IPA). Sergipe: Santo Amaro das Brotas, 19/I/1992, Farney et al. 2001 (RB). Bahia: Ilhéus, Olivença, ca. $6 \mathrm{~km}$ na estrada OlivençaMaruim, 4/XII/1991, Amorim et al. 480 (CEPEC); Nilo Peçanha, Rodovia Nilo PeçanhaCairu km 2, 22/XI/1985, fl., Silva \& Santos 1962 (CEPEC).

Aechmea mertensii possui ampla distribuição geográfica, ocorrendo na Venezuela, Colômbia, Trinidade, Guiana, Suriname, Guiana Francesa, Peru e Brasil (Smith \& Downs 1979). No Brasil, ocorre desde a região norte, nos Estados de Roraima, Amazonas, Rondônia, Acre, Amapá e Pará, chegando até o nordeste nos Estados de Pernambuco, Sergipe, Alagoas, Bahia e Paraíba, 
sendo esta a primeira referência para este Estado. Ocorre como epífita nas matas e em vegetação de restinga, geralmente em densas touceiras. Floresce nos meses de novembro a abril, com frutificação em maio e junho.

Smith \& Downs (1979) consideraram $A$. mertensii relacionada a $A$. paniculata Ruiz \& Pav., A. huebneri Harms e A. ampla L. B. Sm., pela bráctea floral cilíndrica, envolvendo completamente a base do ovário, com margens sobrepostas. Distingue-se, entretanto, destas, pela inflorescência em panícula congesta e sépalas mucronadas.

Apesar de possuir grande variação morfológica e ampla distribuição geográfica, a espécie é facilmente identificada. Observou-se que os espécimes provenientes da região norte, principalmente do Pará, Amazonas e Rondônia, apresentam maior porte, bainha das folhas muito alargada e inflorescências maiores $(20,0$ $40,0 \mathrm{~cm})$ que os exemplares de Pernambuco.

6. Aechmea mulfordïL. B. Sm., Phytologia 19: 281. 1970. nom. nov. para Gravisia fosteriana L. B. Sm., Phytologia 8: 218, pl.1, f. 1, 2. 1962. non Aechmea fosteriana L. B. Sm. (1941). Tipo. Brasil. Bahia: Portoa, 10/VI/ 1939, Foster 84 (Holótipo GH).

Folhas revestidas em ambas as faces por escamas adpressas, lanceoladas, $1,20 \mathrm{~m}$ compr., $5,5 \mathrm{~cm}$ larg., ápice pungente, ca. 6,0 mm compr., margens serradas, espinhos ca. de $2,0 \mathrm{~mm}$ compr.; bainha alargada, castanho-escura, $25,0 \mathrm{~cm}$ compr., $10,0 \mathrm{~cm}$ larg. Escapo ereto, lanuginoso, $45,0 \mathrm{~cm}$ compr. Brácteas do escapo coriáceas, imbricadas, conduplicadas, lanceoladas, ultrapassando os entrenós, ca. 19,0cm compr., 5,5cm larg., ápice acuminado, margens inteiras. Inflorescência composta, panícula laxa, fasciculada na extremidade dos ramos, levemente tomentosa, triangular, ca. $44,0 \mathrm{~cm}$ compr., $58,0 \mathrm{~cm}$ larg., ramos de segunda ordem longos, ca. $13,0 \mathrm{~cm}$. Brácteas primárias papiráceas, patentes, lanceoladas a elípticolanceoladas, 16,0-5,0cm compr., 3,5-1,5cm larg., margens lisas. Brácteas secundárias papiráceas, carenadas, largo-oval, ca. $3,0 \mathrm{~cm}$ compr., ápice pungente, margens inteiras. Bráctea floral semelhante às brácteas secundárias, $2,6 \mathrm{~cm}$ compr., margens inteiras, envolvendo completamente o ovário. Flores sésseis, 3,6-4,0cm compr. Sépalas livres, fortemente assimétricas, ca. $2,0 \mathrm{~cm}$ compr., levemente carenadas, ápice acuminado. Pétalas livres, amarelas, $2,8 \mathrm{~cm}$ de compr., ca. 2,0mm larg., base ligulada, lobo da corola ovado, ápice agudo; apêndices petalinos basais, ca. $4,0 \mathrm{~mm}$ compr. conatos à base das pétalas, porção apical livre, margens erosas. Estames com filete ca. $2,0 \mathrm{~cm}$ compr., antera ca. $6,0 \mathrm{~mm}$ de compr. Estigma cilíndrico, ca. $2,5 \mathrm{~cm}$, lobo espiralado, pouco ultrapassando os estames. Tubo epígino ca. 2,5mm compr. Ovário trígono, ca. $8,0 \mathrm{~mm}$ compr., 5,0 mm larg., liso. Placentação axial, ocupando metade da cavidade do ovário. Óvulos numerosos, caudados. Frutos e sementes não vistos.

Material examinado: BRASIL. Pernambuco: Cabo, Engenho Boa Vista, 9/XI/1968, fl., Lima 50-68 (IPA).

Aechmea mulfordii distribui-se nos Estados de Pernambuco e Bahia.

Gravisia fosteriana foi descrita por Smith (1962) com base na coleta de Foster 84. Posteriormente, Smith (1970) propôs um nome novo, A. mulfordii. Esta espécie apresenta afinidades com $A$. aquilega (Salisb.) Griseb., com base no padrão de inflorescência, brácteas primárias, secundárias e floral. No entanto, a inflorescência de $A$. mulfordii apresenta-se mais laxa, devido aos ramos de segunda ordem serem mais longos (ca. 13,0cm), ao contrário de A. aquilega, com os ramos de segunda ordem mais curtos (ca. $1,0 \mathrm{~cm})$.

A falta de novas coletas de $A$. mulfordii não permitiu melhor compreensão dos limites entre estas duas espécies. É necessário o exame de novas coleções, incluindo o material-tipo desta espécie, visando o melhor estabelecimento dos limites entre $A$. mulfordii e $A$. aquilega, com a possibilidade de constituirem um único táxon. 
7. Aechmea muricata (Arruda) L. B. Sm., Phytologia 8: 12. 1961.

Fig. 3 G-L.

Bromelia muricata Arruda, Diss. sobre as plantas do Brasil: 21. 1810. Tipo. Brasil. Pernambuco: coletor não citado (Holótipo: não localizado).

Planta ca. $70,0 \mathrm{~cm}$ alt. Folhas verdes, lanceoladas, face abaxial com indumento formando uma película esbranquiçada, destacável "in sicco", 0,71-1,87m compr., 3,5-5,5cm larg., ápice pungente, espinho apical ca. $1,0 \mathrm{~cm}$ de compr., margens serradas, espinhos reflexos, ca. $1,0 \mathrm{~mm}$ de compr.; bainha pouco alargada, castanho-escura, $12,0-13,0 \mathrm{~cm}$ compr., $6,0-9,0 \mathrm{~cm}$ larg. Escapo ereto, esverdeado, brancotomentoso, ca. $55,0 \mathrm{~cm}$ de compr. Brácteas do escapo foliáceas, coriáceas, pardacentas, densamente imbricadas, mais largas que os entrenós, encobrindo totalmente o escapo, lanceoladas, 3,0-25,0cm compr., 3,3-3,7cm larg., ápice pungente, margens lisas, as basais serradas. Inflorescência simples, espiga congesta, estrobiliforme, robusta, $16,0 \mathrm{~cm}$ compr., ca. $7,0 \mathrm{~cm}$ larg., muricada. Bráctea floral verdeacinzentada, tomentosa, conduplicada, trígona, ângulos salientes, parte superior mais carnosa que a base, 2,3-2,5cm compr., carenada, aristada, margens inteiras, não envolvendo completamente o ovário. Flores sésseis, 4,0-4,2cm compr. Sépảlas livres, esverdeadas, branco-tomentosas externamente, fortemente assimétricas e contorcidas, $2,0-2,3 \mathrm{~cm}$ compr., ápice fortemente acuminado. Pétalas livres, brancas, com ápice lilás, 3,0-3,3cm compr., ca. 3,0mm larg., base ligulada, lobo da corola lanceolado, margens onduladas; apêndices petalinos calosos, estendendo-se ao longo dos filetes, sem porção terminal livre. Estames com filete de 1,9cm compr; antera $0,8 \mathrm{~cm}$ compr. Estigma cilíndrico, ca. $3,0 \mathrm{~cm}$ compr., lobos espiralados, margens onduladas e granulosas, igualando as anteras. Tubo epígino ca. 5,0mm compr. Ovário cilíndrico, ca. $0,6 \mathrm{~mm}$ compr., $0,5 \mathrm{~cm}$ larg. Placentação apical.
Óvulos numerosos, longo-caudados. Frutos e sementes não vistos.

Material examinado: BRASIL. Pernambuco: Jaboatão dos Guararapes, Restinga de Prazeres, 14/IX/1955, fl., Lima 55-2135 (PEUFR); Nazaré da Mata, Engenho Cavalcante, 17/XI/1965, fl., Andrade-Lima 63-4318 (IPA); Recife, Entre Afogados e Boa Viagem, 24/II/1939, fl, Baker \& Collins s.n. (SPF 72156; SP 41740); São Lourenço da Mata, Mata do Toró, 22/XI/1995, fl., Sousa et al. 169 (UFP).

Aechmea muricata é endêmica do Estado de Pernambuco, ocorrendo predominantemente como epífita na mata. Floresce nos meses de setembro a novembro, sendo visitada por beija-flores. Frutifica de dezembro a fevereiro.

Aechmea muricata apresenta semelhança morfológica com as espécies dos subgêneros Macrochordion e Pothuava, pela presença de inflorescência estrobiliforme. A. ornata (Gaudich.) Baker do subg. Pothuava é semelhante a A. muricata. Ambas apresentam folhas totalmente cobertas por escamas, formando uma película esbranquiçada destacável quando seca, inflorescência estrobiliforme e bráctea floral carenada e aristada. Porém, distinguem-se pelas brácteas do escapo, bráctea floral e pétalas avermelhadas em $A$. ornata.

Foram percorridos todos os locais de ocorrência conhecidos desta espécie. No entanto, só foi encontrada na Reserva Ecológica de Tapacurá, município de São Lourenço da Mata, provavelmente por tratar-se de área ainda protegida. É provável que esta espécie esteja em perigo de extinção pela contínua derrubada de árvores na região e por ser espécie com pequenas populações no ambiente onde vive.

8. Aechmea stelligera L. B. Sm., Smithsoniam. Misc. Collect.126: 18. 1955. Tipo. Brasil. Paraíba: Areia, 15/IX/1944, Vasconcelos s.n. (Holótipo US; Isótipo SP 52358!, EAN 862!). Fig. 4 A-F.

Planta ca. 1,30m alt. Folhas verdes, lanceoladas, escamosas, 0,62-1,30m compr., 4,1- 
$6,0 \mathrm{~cm}$ larg., ápice pungente, ca. 1,0cm compr., margens densamente serradas, espinhos negros até $4,5 \mathrm{~mm}$ compr.; bainha castanho-escura, alargada, 16,0-23,0cm compr., 8,0-12,0cm larg. Escapo ereto, vináceo, levemente brancotomentoso, 45,0-62,0cm compr. Brácteas do escapo papiráceas, vermelhas, espiraladas, ovallanceoladas, ápice pungente, mais longas que os entrenós, 16,0-18,0cm compr., 4,0-5,0cm larg., as basais foliáceas, margens serradas. Inflorescência composta, panícula amplamente ramificada, laxa, levemente tomentosa, piramidal, ramificações angulosas, 35,0-38,0 cm compr., 28,0-38,0cm larg. Brácteas primárias papiráceas, vermelhas, semelhantes às brácteas superiores do escapo, oval-lanceoladas, 2,5$14,0 \mathrm{~cm}$ compr., $0,4-4,5 \mathrm{~cm}$ larg., patentes, protegendo os ramos florais, diminuindo para o ápice. Brácteas secundárias papiráceas, vermelhas, lanceoladas, 2,0-4,0 cm compr., 2,5-3,0 mm larg. Bráctea floral coriácea, verde-claro, triangular, diminuta, 2,3-3,0mm compr., brancotomentosa na face dorsal, ápice longoacuminado, margem inteira, mais curta e não envolvendo o ovário. Flores sésseis, 2,7-3,1cm compr. Sépalas livres, amarelo-esverdeadas, tomentosas na porção mediana, fortemente assimétricas, torcidas, ca. $1,3 \mathrm{~cm}$ compr., ápice acuminado. Pétalas livres, amarelas, ca. $2,4 \mathrm{~cm}$ compr., 5,0mm larg., base ligulada, lobo da corola lanceolado, ápice mucronado; apêndices petalinos basais, ca. $1,5 \mathrm{~mm}$ compr., conatos às pétalas na porção basal, parte superior livre, margens erosas. Estames atingindo o ápice das pétalas, filete ca. $1,9 \mathrm{~cm}$ compr.; anteras $9,0 \mathrm{~mm}$ compr. Estigma cilíndrico, ca. $2,5 \mathrm{~cm}$ compr., ultrapassando a altura das anteras, lobos espiralados, margens onduladas e densamente glandulosas. Tubo epígino ca. $1,5 \mathrm{~mm}$ compr. Ovário clavado, verde, branco-tomentoso, ca. 6,0mm compr., 5,0mm larg. Placentação axial, ocupando ca. da metade da cavidade do ovário. Óvulos numerosos, caudados. Fruto e sementes não vistos.

Material examinado: BRASIL. Pernam- buco: Bonito, Reserva Ecológica de Bonito, 18/IX/1995, Sousa et al. 160 (UFP); Maraial, Lagoa dos Gatos, 28/XI/1995, Sousa et al. 170 (UFP); Quipapá, Engenho Brejinho, 15/IX/1972, fl., Pontual 72-1233 (PEUFR); 2/IX/1980, fl., Brito /8(IPA); São Benedito do Sul, Mijada da Veia, 28/XI/1995, Sousa et al. 171 (UFP); Vicência, Engenho Jundiaí, 28/IX/1968, fl., Pontual 68-861 (PEUFR); Brejo Seco, 6/IX/1986, Sales et al. 60 (PEUFR).

Material adicional selecionado: BRASIL. Alagoas: Maceió, Parque do Catolé, 18/IX/1979, fl., Nunes et al. s.n. (EAC 6969); União dos Palmares, Engenho Santo Antônio, 1/XI/1966, Pontual 66-233 (PEUFR). Paraíba: Alagoinha, Estação experimental, 1942, Xavier s.n. (JPB 781); Areia, 1939, Xavier s.n. (JPB 09).

Aechmea stelligera é registrada pela primeira vez para o Estado de Pernambuco, ocorrendo ainda nos Estados da Paraíba e Alagoas. Pode ocorrer como epífita ou terrestre nas matas. Floresce nos meses de junho a setembro, com maior ocorrência no mês de setembro.

De acordo com Smith (1955), esta espécie possui afinidades com A. tomentosa $\mathrm{Mez}$ pelo padrão de inflorescência, bráctea floral e coloração das peças florais. No entanto, em $A$. stelligera a inflorescência é sempre laxa, com ramos da inflorescência mais longos. Nota-se também escapo, bráctea floral, ovário e sépalas com indumento menos denso do que em $A$. tomentosa.

Apesar deste táxon formar grandes populações nos locais de ocorrência, as coletas são escassas para o Estado, provavelmente por ser, em sua grande maioria, epífita em árvores de grandes porte.

9. Aechmea tomentosa Mez in A. DC. \& C. DC., Monogr. phan. 9: 229. 1896.Tipo. Brasil. Pernambuco: Igaraçu, 1887, Ramage s.n. (Holótipo BM; Foto GH).

Fig. 4 G-L.

Planta ca. $60 \mathrm{~cm}$ alt. Folhas verdes, 


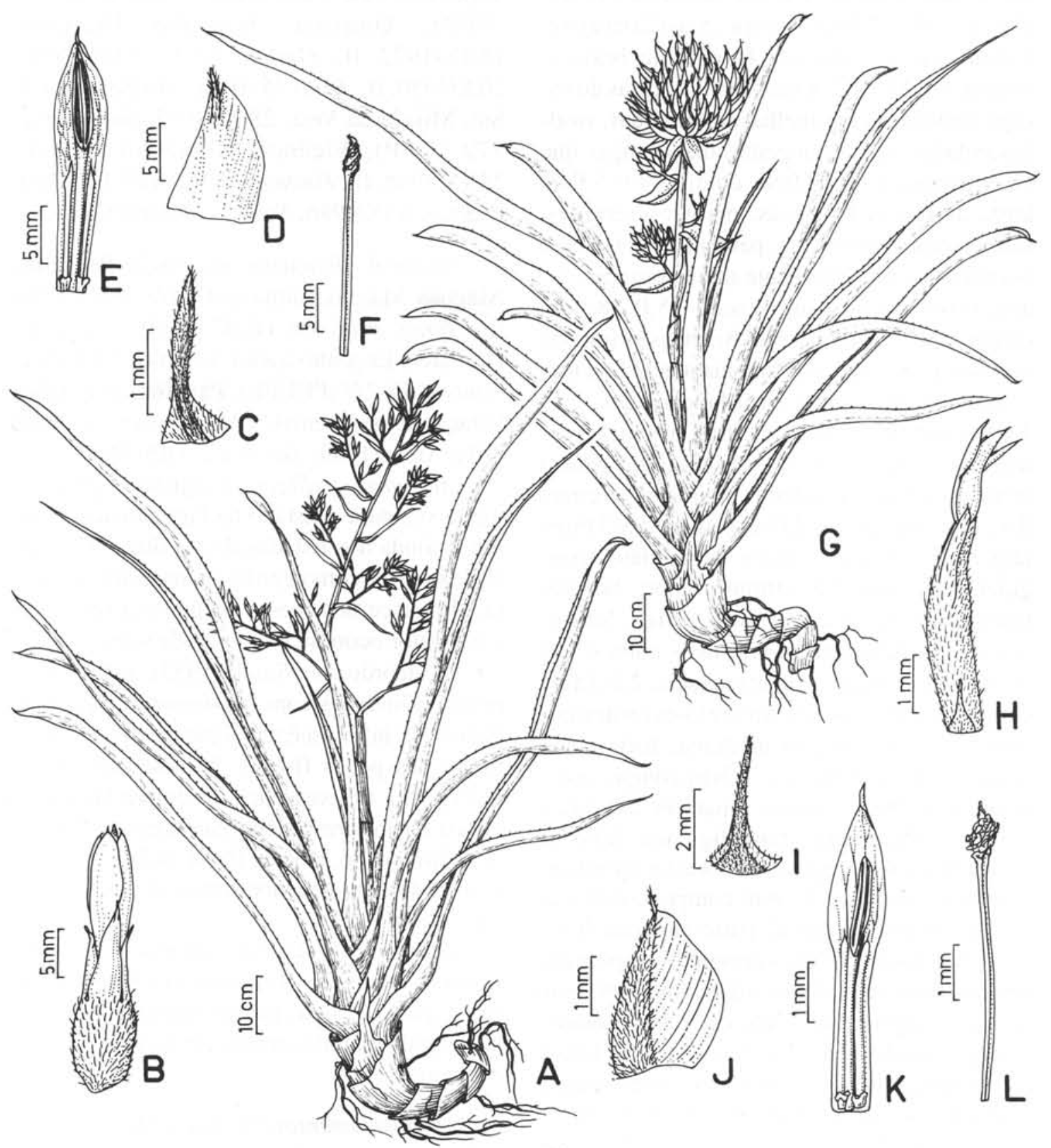

Figura 4. A-F. Aechmea stelligera. A. hábito; B. flor; C. bráctea floral; D. sépala; E. pétala, estame e apêndices petalinos; F. estilete e estigma (Sousa et al. 160). G-L. Aechmea tomentosa. G. hábito; H. flor; I. bráctea floral; J. sépala; K. pétala, estame e apêndices petalinos; L. estilete e estigma (Sousa et al. 149). 
lanceoladas, revestidas em ambas as faces por escamas adpressas, 0,42-1,38m compr., 3,3$7,0 \mathrm{~cm}$ larg., ápice pungente, ca. 0,6-1,5cm compr., margens densamente serradas, espinhos irregularmente dispostos, de tamanhos diversos, os maiores ca. $4,0 \mathrm{~mm}$ compr.; bainha marronescura ou vinácea, 12,0-24,0cm compr., 5,8$18,0 \mathrm{~cm}$ larg. Escapo ereto, cilíndrico, vináceo, espesso, branco-tomentoso, 18,0-50,0 cm compr. Brácteas do escapo papiráceas, imbricadas com escamas adpressas, vistosas, vermelhas, ovallanceoladas, mais longas que os entrenós, revestindo completamente o escapo, $13,0-17,0 \mathrm{~cm}$ compr., 3,5-6,0cm larg., as basais foliáceas, ápice pungente e margens serradas, as superiores geralmente ultrapassando os dois ramos basais, margens lisas. Inflorescência composta, panícula, piramidal, 14,0-27,0cm compr., 6,0$10,0 \mathrm{~cm}$ larg., densamente escamoso-tomentosa, tricomas estrelados. Brácteas primárias semelhantes às brácteas superiores do escapo, papiráceas, vermelhas, cimbiformes, $1,8-15,0 \mathrm{~cm}$ compr., 0,4-6,0 cm larg., patentes, as basais protegendo quase completamente os ramos florais, as superiores lanceoladas, distintamente menores no ápice. Bráctea secundária diminuta, escamiforme, acuminada, branco-tomentosa, ca. 4,0mm compr. Bráctea floral diminuta, semelhante às secundárias, longo-acuminada, 1,0$0,3 \mathrm{~cm}$ compr., menor que o ovário. Flores sésseis, 4,7-5,0cm compr. Sépalas livres, amarelo-esverdeadas, branco-tomentosas externamente, fortemente assimétricas, imbricadas, 1,5$1,8 \mathrm{~cm}$ compr., mucronadas, múcron ca. $1,8 \mathrm{~mm}$. Pétalas livres, amarelas, 4,9-5,1 cm compr., ca. $5,0 \mathrm{~mm}$ larg., base ligulada, lobo da corola lanceolado, ápice mucronado; apêndices petalinos basais ca. $1,5 \mathrm{~mm}$ compr., conatos à base das pétalas, parte superior mais larga e livre, formando uma pequena "bolsa", margens erosas, calosidade presente a partir da base da pétala até o terço inferior do lobo da corola, onde é mais dilatada. Estames com filete ca. $2,5 \mathrm{~cm}$ compr.; anteras ca. $1,0 \mathrm{~cm}$ compr. Estigma cilíndrico ca. $3,7 \mathrm{~cm}$ compr., lobos espiralados, margens onduladas e glandulosas, ultrapassando os estames. Tubo epígino ca. 4,0mm compr. Ovário cilíndrico, verde, branco-tomentoso, ca. $1,4 \mathrm{~cm}$ compr., 6,0mm larg. Placentação axial, ocupando metade da cavidade do ovário. Óvulos numerosos, caudados. Fruto e sementes não vistos.

Material examinado: BRASIL. Pernambuco: Bezerros, Engenho Riachão, 1/XI/1959, fl., Andrade-Lima 59-3388(IPA); Paudalho, Próximo a Academia de Polícia Militar, 26/VIII/1995, fl., Sousa et al. 149 (UFP); Rio Formoso 28/VIII/1954, Pereira 868 (HB); 28/V/1954, fl., Falcão et al. 868 (IPA); Praia dos Carneiros, 4/I/1968, fl., Lima 38-68 (IPA); São Lourenço da Mata, Mata do Toró, 26/VIII/1980, Andrade-Lima \& Bocage 13 (IPA); 29/IX/1995, Sousa et al. 164 (UFP); São Lourenço da Mata, Tapera, 26/VII/1932, fl., Pickel s.n. (IPA 3496); Tamandaré, Reserva Biológica de Saltinho, 2/IX/1998, Martinelli 15131 (RB).

Material adicional selecionado: BRASIL. Alagoas: Porto Calvo, Engenho Oriente, 14/VIII/1960, Andrade-Lima 60-3512 (IPA); União dos Palmares, Engenho Santo Antônio, 1/XI/1966, Pontual 66-233 (IPA).

Aechmea tomentosa é restrita ao nordeste do Brasil, nos Estados de Pernambuco e Alagoas. Ocorre nas matas, preferencialmente como epífita. Floresce de julho a novembro, tendo maior expressividade no mês de agosto. Foram observadas visitas de formigas e beija-flores em suas inflorescências.

Aechmea tomentosa apresenta afinidades morfológicas com A. stelligera L. B. Sm., pertencentes ao mesmo subgênero, diferindo desta principalmente pelo indumento mais denso e branco-tomentoso no escapo, brácteas primárias cimbiformes, inflorescência geralmente congesta com densa pilosidade em todas as peças florais, exceto nas pétalas, e flores relativamente grandes (ca. $5,0 \mathrm{~cm}$ ). Pelo padrão de inflorescência, com presença de ramos de terceira ordem, assemelha-se também a $A$. 
werdermannii, distinguindo-se essencialmente pela inflorescência glabra nesta última.

Em expedições de coleta pelo Estado de Pernambuco, observou-se que a espécie encontra-se em áreas restritas, com pequeno número de indivíduos, justificando a pouca representatividade nos herbários, além de habitarem árvores de grande porte, cuja altura geralmente ultrapassa 10 metros.

10. Aechmea werdermannï Harms, Notizbl. Bot. Gart. Berlin. 12: 529. 1935. Tipo. Brasil. Pernambuco: Floresta, Serra Negra, 1932, Werdermann 2911 (Holótipo B!; Foto B 1192/36).

Folhas lanceoladas, escamosas, 65,0$1,50 \mathrm{~cm}$ compr., 3,0-4,0cm larg., ápice pungente, ca. $0,5 \mathrm{~cm}$ compr., margem densamente serrada, espinhos negros até $3,0 \mathrm{~mm}$ compr.; bainha castanho-avermelhado, $12,5 \mathrm{~cm}$ compr., $5,5 \mathrm{~cm}$ larg. Inflorescência composta, panícula amplamente ramificada, laxa, glabra, ca. $40,0 \mathrm{~cm}$, ramos basais $20,0-30,0 \mathrm{~cm}$ compr. Brácteas do escapo paleáceas, ca. $20,0 \mathrm{~cm}$ compr., amplexiescapo, curto-laminadas. Brácteas primárias papiráceas, róseas, lanceoladas, 2,0-12,0cm compr., 1,5-2,0cm larg., patentes, diminuindo para o ápice, margens inteiras. Bráctea secundária membranácea, inconspícua, lanceolada, 0,5-1,0cm compr., $3,0 \mathrm{~mm}$ larg., margem inteira. Bráctea floral triangular, membranácea, diminuta, ca. $5,0 \mathrm{~mm}$ compr., ca. 3,0mm larg., mais curta que o ovário, ápice longo-acuminado, margens inteiras, glabra. Flores sésseis, ca. 3,5cm compr. Sépalas livres, fortemente assimétricas, torcidas, margens involutas, ca. 1,3-1,5cm compr., ápice mucronado. Pétalas livres, amarelas, ca. $2,5 \mathrm{~cm}$ compr., 2,5mm larg.; base ligulada, lobo da corola lanceolado, apêndices petalinos basais ca. $1,5 \mathrm{~mm}$ compr., conatos às pétalas na porção basal, parte superior livre, margens erosas. Estames atingindo o ápice das pétalas, filete ca. 2,0 cm compr.; anteras 9,0 mm compr. Estigma cilíndrico, ca. 2,5cm compr., lobos espiralados, ultrapassando os estames. Tubo epígino ca. 2,0mm compr. Ovário cilíndrico, ca. 7,0mm compr. Placentação axial; ocupando toda a cavidade do ovário, óvulos numerosos, caudados. Fruto e sementes não vistos.

Material examinado: BRASIL. Pernambuco: Floresta, Reserva Biológica de Serra Negra, 26/VI/1996, Pimentel et al. 113 (PEUFR); Inajá, Reserva Biológica de Serra Negra, 8/III/1995, Sousa et al. 69 (PEUFR, SP); 8/VIII/1998, Martinelli 15043(RB).

Até o presente, $A$. werdermannii é considerada endêmica do Estado de Pernambuco. Anteriormente conhecida apenas pela coleta do material-tipo, foi recentemente recoletada na mesma área.

Aechmea werdermannii tem afinidade com A. stelligera L. B. Sm. e A. tomentosa Mez, pela inflorescência tripinada, que varia quanto ao comprimento das ramificações, sendo gradativamente maiores em $A$. werdermannï e menores em $A$. tomentosa, cuja a inflorescência é mais densa e globosa. As flores de $A$. werdermannii possuem sépalas, pétalas e apêndices petalinos com forma e tamanho semelhantes aos de A. stelligera, porém esta espécie possui brácteas florais distintamente menores. As características intermediárias ocorrentes em $A$. tomentosa levaram à suposição de que este táxon poderia ser um híbrido entre $A$. werdermannii e A. stelligera. Observa-se ainda em $A$. tomentosa, flores maiores e com pilosidade mais densa que nas duas espécies acima mencionadas.

Harms (1935) considerou A. werdermannii próxima a $A$. spectabilis Brongn. ex Houllet, espécie da Colômbia e Venezuela, diferindo as duas pelas flores bem menores nesta última espécie.

O gênero Aechmea, o maior em número de espécies da subfamília Bromelioideae, apresenta delimitação bastante complexa e polêmica. Baker (1879), no primeiro tratamento para a família Bromeliaceae, propôs para o gênero nove secções. Dez anos depois, este mesmo autor reu- 
niu as espécies de Aechmea em 11 subgêneros, que foram posteriormente reduzidos a nove (Mez 1891-1892;1896;1935; Harms 1930). Mais recentemente, Smith \& Downs (1979) consideraram oito subgêneros para Aechmea. Apesar de Smith \& Kress (1989) terem elevado ao nível de gênero sete dos oito subgêneros considerados por Smith \& Downs (1979), no presente trabalho foi seguida a proposta de Smith \& Downs (1979).

As principais características utilizadas para separar os subgêneros estão relacionadas com o padrão da inflorescência, presença ou ausência de pedicelo e morfologia das sépalas. Observase que alguns subgêneros reúnem espécies que estariam melhor posicionadas em outros subgêneros, ou mesmo em outros gêneros afins de Aechmea. Sente-se, portanto, a necessidade de melhor estudo dos limites infragenéricos neste gênero. O subgênero Chevaliera, ao qual pertence $A$. muricata, parece ser um dos mais naturais, reunindo grupo de espécies com grandes inflorescências estrobiliformes e brácteas florais conspícuas e espessas.

Dentre as espécies estudadas, oito pertencem ao subgênero Aechmea, que inclui cerca de 72 espécies, representando cerca de $41 \%$ do total de aproximadamente 172 espécies do gênero. O subgênero Aechmea é bastante artificial, reunindo espécies com inflorescências simples a compostas, laxas ou densas, com flores dísticas a polísticas e sépalas sem espinho apical ou mucronadas (Smith \& Downs 1979).

Entre as espécies deste subgênero observase que $A$. stelligera, $A$. tomentosa, $A$. werdermannii, A. eurycorymbus, A. mulfordii $\mathrm{e}$ A. aquilega são as mais relacionadas, apresentando inflorescências compostas, com padrão de ramificação semelhante, flores vistosas e grandes, com apêndices petalóides bastante desenvolvidos. A inflorescência nestas espécies é muito característica, consistindo em uma panícula amplamente ramificada, variando entre as espécies quanto ao comprimento dos ramos, sendo mais longos em $A$. mulfordii, tor- nando-se mais reduzidos em $A$. tomentosa, onde a inflorescência tem forma globosa. $A$. werdermannii é muito semelhante a $A$. eurycorymbus e $A$. tomentosa semelhante a $A$. stelligera. Estas espécies apresentam, em geral, escassez de material disponível nos herbários, provavelmente pela dificuldade de coletas, sendo algumas delas de áreas restritas e epífitas em árvores de grande altura.

Procurou-se, no presente trabalho, reencontrar as espécies na localidade dos materiais-tipos, sendo $A$. werdermanii espécie endêmica para Pernambuco, cujo material-tipo é de 1932 , novamente coletada em 1996, na mesma localidade do tipo (Reserva de Serra Negra). Posteriormente, duas novas coletas foram obtidas na mesma região. $A$. tomentosa, espécie referida também para o Estado de Alagoas, foi novamente encontrada no local do tipo, constituindo, como a anterior, espécies raras e ameaçadas de extinção. Apesar das inúmeras buscas, não foi reencontrada $A$. eurycorymbus, sendo conhecida apenas pelo material-tipo desta espécie.

Aechmea aquilega e $A$. mulfordii apresentam afinidades, distinguindo-se das demais deste grupo pelas inflorêscências com ramos apicais fasciculados e mais densos. Separam-se entre si pelo comprimento dos ramos da inflorescência, sendo mais longos em $A$. mulfordii. A possibilidade de constituírem uma única espécie é possível.

Aechmea fulgens pertence ao subgênero Lamprococcus, com cerca de 13 espécies, representando 7\% do gênero Aechmea (Smith \& Downs 1979). Esse subgênero é caracterizado pelas inflorescências geralmente compostas e sépalas desarmadas, como a maioria dos táxons ocorrentes no Brasil. A. fulgens apresenta inflorescências semelhantes às de $A$. miniata (Beer) ex Baker, e A. warasii E. Pereira, espécies provavelmente relacionadas.

O subgênero Chevaliera possui 21 espécies, destas, 18 ocorrem no Brasil, sendo algumas exclusivas para o nordeste, como $A$. depres$s a \mathrm{~L}$. B. Sm., A. digitata L. B. Sm., A. conifera 
L. B. Sm., A. leucolepsis L. B. Sm., com registro destas espécies, até o presente momento, apenas para o Estado da Bahia (Smith \& Downs 1979).

Aechmea muricata constitui a única representante do subgênero Chevaliera em Pernambuco. Este subgênero caracteriza-se pela inflorescência robusta e estrobiliforme, com cerca de 21 espécies, representando $12 \%$ das espécies do gênero Aechmea (Smith \& Downs 1979). Apesar deste padrão de inflorescência ocorrer nos subgêneros Macrochordion (de Vriese) Baker e Pothuava (Baker) Baker, o subgênero Chevaliera separa-se dos demais por apresentar apêndices petalinos reduzidos ou ausentes. Estas estruturas petalóides em Bromeliaceae constituem importante característica floral na família, sendo de grande valor diagnóstico na separação de gêneros, ou mesmo específico, especialmente no subgênero Aechmea. Brown \& Terry (1992) vêm estudando estes apêndices, entretanto a função dos mesmos ainda não é totalmente clara.

Das 10 espécies estudadas no presente trabalho, sete foram novamente coletadas, o que permitiu o melhor conhecimento da variabilidade morfológica apresentada para cada espécie e as prováveis relações entre as mesmas.

Em relação ao padrão de distribuição geográfica, foram observados dois padrões: 1 Ampla distribuição geográfica: da Costa Rica até o Sudeste do Brasil (A. lingulata), da Colômbia até o Nordeste do Brasil ( $A$. mertensii). 2 - Restrita ao Brasil: 2.1 - presente no nordeste, estendendo-se até o sudeste ( $A$. fulgens e $A$. aquilega). 2.2 - exclusiva do nordeste brasileiro, ocorrendo nos Estados do Ceará, Paraíba, Pernambuco, Alagoas e Bahia (A. eurycorymbus, A. mulfordii, A. stelligera e A. tomentosa). 2.3 endêmicas do Estado de Pernambuco ( $A$. muricata e $A$. werdermannii).

Com base no presente estudo, verifica-se a necessidade de estudo mais detalhado para o gênero Aechmea, que inclua não apenas o conhecimento da variação populacional, mas também o uso de caracteres adicionais, como a morfologia polínica e anatomia foliar. A revisão dos subgêneros de Aechmea é necessária, o que possibilitará o melhor conhecimento da circunscrição do gênero.

\section{Agradecimentos}

As autoras agradecem aos curadores dos herbários citados, pelo empréstimo e envio do material estudado; ao Dr. Simon Mayo, do Royal Botanical Gardens, Kew, Inglaterra, pelas sugestões e ajuda na obtenção de obras raras; ao Prof. Marccus Vinicius Alves, da Universidade Federal de Pernambuco, pelas sugestões, e ao pesquisador Dr. Jefferson Prado, pelas valiosas sugestões.

\section{Referências bibliográficas}

Andrade-Lima, D. 1960. Estudos Fitogeográficos de Pernambuco. Arquivos do Instituto de Agricultura Indústria e Comércio - IPA. Boletím Técnico n. 8, Pernambuco.

Andrade-Lima, D. 1966a. Bromeliaceae de Pernambuco. Publicações da Secretaria de Cultura, Pesquisas Agronômicas - IPA, 5: 376p., Pernambuco.

Andrade-Lima, D. 1966b. Esboço fitogeográfico de alguns brejos de Pernambuco. Secretaria da Indústria e Comércio-IPA, 27p., Pernambuco.

Baker, J. G. 1879. A synopsis of the genus Aechmea Ruiz \& Pav. Journal of Botany 17: 129-135; 161-168; 226236.

Barbosa, M. C. A. \& Barbosa, M. R. V. 1996. Pp. $145-$ 150. Os Herbários do Nordeste. In: E. V. S. B. Sampaio; S. J. Mayo \& M. R. de V. Barbosa (Eds.), Pesquisa Botânica Nordestina: progresso e perspectivas, SBB, Recife.

Brown, G. K. \& Terry, R. G. 1992. Petal appendages in Bromeliaceae. American Journal of Botany. 79(9): 1051-7071.

Brummitt, R. K. \& Powell, C. E. 1992. Authors of plant names. Royal Botanic Gardens, Kew.

Font Quer, P. 1993. Dicionário de Botânica. Ed. Labor, Barcelona.

Grisebach, G. 1864. Aechmea. A. aquilega. Flora of British West Indies. p. 592.

Harms, H. 1930. Bromeliaceae. Pp. 65-159. In: H. G. A. Engler \& K. A. E. Prantl (Eds.), Die naturlichen Pflanzenfamilien. (Wilhelm Engelmann). 2Aufl, 15a, Leipzig.

Harms, H. 1935. Aechmea eurycorymbuslA. werdermannii. Notizblatt des Königlichen botanischen Gartens und Museums zu Berlim 12: 528-529. 
Holmgren, P. K.; Holmgren, N. H. \& Barnet, L. C. 1990. Index Herbariorum, Part. 1: The herbaria of the world. 8 ed. New York Botanical Garden, New York.

Mez, C. 1891-1892. Bromeliaceae. In: C. F. P. Martius; A. W. Eichler \& I. Urban (Eds.), Flora Brasiliensis 3(3): 173-643, Typographia Regia, Leipzig.

Mez, C. 1896. Bromeliaceae. In: A. P. P. de Candolle \& A. C. P. de Candolle (Eds.), Monographiae phanerogamarum 9: 1-990p. Paris.

Mez, C. 1935. Bromeliaceae. In: H.G.A. Engler (Ed.), Das Pflanzenreich. (Wilhelm Engelmann), 100, IV(32):1667, Berlin.

Radford, A. E.; Dickison, W. C. \& Massey, J. R. 1974. Vascular plant systematics. Harper \& Row, New York.

Read, R. W. \& Luther, H. E. 1991. The Aechmea/Gravisia complex (Bromeliaceae). Selbyana 12: 54-67.

Salisbury, R. A. \& Hooker, W. 1806. Bromelia aquilega. The Paradisus Londinensis 1(1): 40.

Smith, L. B. 1955. Bromeliaceae of Brazil. Smithsonian Miscellaneous Collections 126(1): 254p.
Smith, L. B. 1962. Gravisia fosteriana. Phytologia 8(1): 218.

Smith, L. B. 1970. Notes on Bromeliaceae, XXX. Phytologia 19(4): 281.

Smith, L. B. \& Downs, R. J. 1979. Bromelioideae (Bromeliaceae). Flora Neotropica. Hafner Press. Monograph 14 (3): 1493-2141, New York.

Smith, L. B. \& Kress, W. J. 1989. New or restored genera of Bromeliaceae. Phytologia 66(1): 70-79.

Stafleu, F. A \& Cowan, R. S. 1976-1988. Taxonomic literature. $2^{\text {a }}$ Edition. Bohn, Scheltema \& Holkema (Eds.), 7 vols., Utrecht.

Stearn, W. T. 1992. Botanical Latin. David \& Charles (Eds.). $4^{a}$ edição, London.

Vasconcelos Sobrinho, J. 1971. As regiões naturais do nordeste, o meio e a civilização. Conselho de Desenvolvimento de Pernambuco, Recife. 